\title{
Foundations and Foundation Myths of the Troubadours
}

\author{
Wendy Pfeffer \\ University of Louisville / University of Pennsylvania \\ pfeffer@louisville.edu \\ https://orcid.org/OOOO-OOO2-9902-403I
}

Received 22/04/2Org; accepted 02/o7/2019

DOI: https://doi.org/IO.7203/MCLM.6.I48I5

\begin{abstract}
A review of several origin myths relating to the creation of medieval Occitan lyric poetry. We see a preference for a "great man theory" of origins, though the "great man" may be a fictional woman. Medieval and Renaissance Occitan authors, including Uc de Saint Circ, Guilhem Molinier, and Jean de Nostredame, used differing origin myths to validate literature in a language that was perceived not to carry the prestige of twelfth- and thirteenth-century Latin or fifteenth- and sixteenth-century French.
\end{abstract}

\section{KeYwords}

troubadours; Occitan literature; charter myths; foundation myths; Guilhem IX de Peitieus; Uc de Saint Circ; Jean de Nostredame; Guilhem Molinier; Consistori de gaia sciensa; Eble II de Ventadorn; Clémence Isaure

\section{RESUM}

Revisió d'alguns mites d’origen referits a la creació de la poesia lírica occitana medieval. Hi veiem una preferència per una "teoria del gran home" d'origen, tot i que el "gran home" també podria ser una dona de ficció. Autors medievals i renaixentistes, incloent-hi Uc de Sant Circ, Guilhme Molinier i Jean de Nostredame, van emprar mites d'origen divergents per a validar la literatura en una llengua que es percebia que no comportava el prestigi del llatí dels segles xii i xiii, o el del francès dels segles xiv i Xv.

PARAULES CLAU

trobadors; literatura Occitana; mites justificadors; mites fundacionals; Guilhem IX de Peitieu; Uc de Sant Circ; Jean de Nostredame; Guilhem Molinier; Consistori de la Gaia Ciència; Eble II de Ventadorn; Clémence Isaure

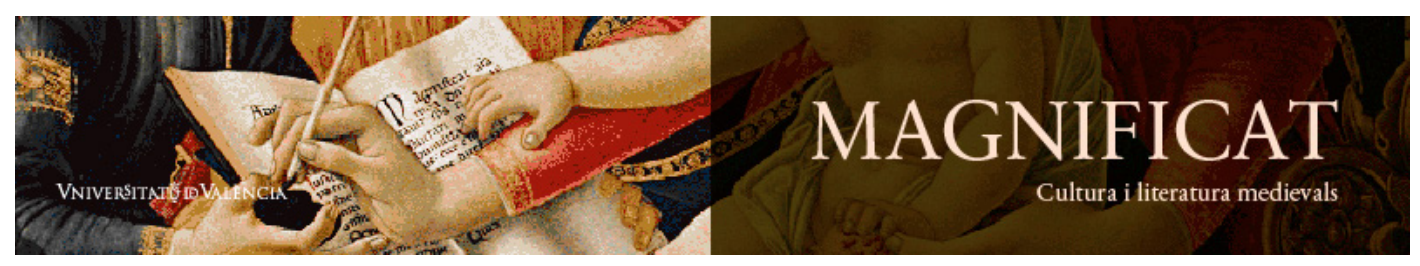

Magnificat Cultura i Literatura Medievals 6, 2019, I85-205. http://ojs.uv.es/index.php/MCLM

ISSN $2386-8295$ 
Wendy Pfeffer. 2019. 'Foundations and Foundation Myths of the Troubadours', Magnificat Cultura $i$ Literatura Medievals, 6: 185-205

\section{TABLE OF CONTENTS}

Introduction - 187

${ }_{2}$ Theoretical Arguments - 187

3 The First Fathers - 188

4 Uc de Saint Circ and the vidas - I9I

5 Consistory of Gay Science - 192

6 The Sixteenth Century - 196

7 Jean de Nostredame (1522-76/7) - I99

8 Conclusion - 200

9 Acknowledgements - $2 \mathrm{OI}$

Io Works Cited - 202 


\section{ə*⿻}

\section{Introduction}

This article considers multiple foundation myths of troubadour lyric, as a means of better understanding the myths themselves and in order to consider what their function might be. Even the individual modern scholars consider as the first named troubadour, Guilhem IX, seventh Count of Poitiers, ${ }^{\mathrm{I}}$ implied in his poetry that he had predecessors. His successors identified other founding poets or patrons, notably Eble of Ventadorn (IO86-II55). Later in the history of troubadour lyric, additional foundation myths were created, culminating, one might say, with a late fifteenth-century creation that was truly mythic and totally fictional, the invention of Clémence Isaure as founding sponsor of Occitan lyric. This article will outline this history from Guilhem to Clémence and on to Jean de Nostradame, concluding that the several creation myths relate to the status of Occitan literary creation in the face of linguistic competition from Latin and French.

\section{Theoretical Arguments}

$\mathrm{T}$ he terms foundation myth and charter myth are interchangeable. One definition of such a myth is a tale that, according to Bronislaw Malinowski, "conveys, expresses, and strengthens the fundamental facts of the local unity and of the kinship unity of the group of people" (I954: II6). "It is always made $a d$ hoc to fulfill a certain sociological function, to glorify a certain group, or to justify an anomalous status" (Malinowski 1954: I25). Charter myths "express the sense of the social group's relationship, whether it be with its legendary members and those no longer living, or with the groups that surround it" (Lévy-Bruhl I999, apud Costa 2009: 7).

It is within human nature to establish a story of self, as anthropologists know well. Furthermore, in the realm of language, as Paul Kroskrity summarizes (2OO9: 73, citing House 2002; Gomez de García et al. 2009; Dorian 1998):

A community's conceptions of its language are critically influenced by its position in political economic and other relevant cultural systems. Those who have political economic power will rationalize inequality by viewing their language as superior and their linguistic practices as exemplary. Those whose languages do not enjoy the hegemonic support of nation-states must either resist by locating authority in alternative, local sources or submit to dominant views that equate linguistic vitality with linguistic superiority thereby conceding their own linguistic inferiority.

Language communities are capable of creating a myth that explains their origins, an effort to present language and discourse "constructed in the interest of a specific social or cultural group" (Kroskrity 2009: 72-73). As James Costa has noted (2009: 5), "Language histories can be one of those places where discourse shapes or intends to shape social structures and transforms or seeks to transform power relationships".

I. Guilhem's status as first named troubadour dates only from the nineteenth century. This consideration is widespread, as Wikipedia shows (https://tinyurl.com/y5koguu4, accessed O2-O2-2OI9). Jean de Nostredame (I522${ }_{57} 6 / 7$ ) may have considered Jaufre Rudel the first troubadour (see below). 
In the case considered here, the myths developed all revolve around a single individual, credited with being the first creator or the founder of a movement. I dub these "great man myths" because the story retold is predicated on a single individual as the origin, most often a male, though the Occitan case presents a female founder with founding myth as well.

\section{The First Fathers}

Modern scholars identify Guilhem IX (William IX) of Aquitaine (IOZI-II26) as the first troubadour. Certainly, we have no attributed poetry to any Occitan lyricist from before his time. His poetic skill is so remarkable that it is generally believed he must have had predecessors whose names are lost to us, though, as Gerald Bond observes, "because his is the first poetry to be preserved, it inevitably appears to be itself the source of most of the later developments in troubadour poetry" (I982: 1vi, my italics). In at least one of Guilhem's lyrics, "Farai un vers de dreit nïen" (PC I83,7), the poet parodies other works, in specific, "the content (a chaste, distant love) and the form (a love-sick lament) of an existing type of love poetry" (Bond ed. I982: lxix, also Bond ed. I982: xlvii), implying predecessors. It is worth noting that his vida, a biography composed long after Guilhem's death, makes no mention of his primordial status or his chronological pre-eminence (Boutière-Schutz ed. 1964: 3).

We cannot easily explain why this nobleman composed verse that has come down to us; Gerald Bond suggests that Guilhem benefitted from a socio-political climate in flux: "The count could erect and defend a 'modern' and 'rustic' poetics which would rapidly raise the value of secular culture and of the culture of the secular - south of the Loire" (Bond 2OI7: I22). His avoidance of Latin was, in part, a political statement: citing Bond again, "He sought to avoid subjection by other figures of power, whether papal, royal, or comital” (2OI7: I28). Latin was the language of the pope, of decrees from the King of France or the King of England, from his French-speaking neighbors north of the Loire. He may have used Occitan to establish himself firmly in his lands and securely as a poet. ${ }^{2}$ However, Guilhem does not figure as an early mythological founder.

The next generation of Occitan poets features Marcabru (flourished circa IIIO-circa II50), who did not describe himself with the term troubadour. For him, as for his immediate contemporaries, troubadour did not carry positive connotations. As William Paden has demonstrated conclusively (2019: I4-I8):

In medieval Occitan, trobador was not a technical term. It did not include all the people we call troubadours, at least not originally. As used by the early troubadours, it was judgmental. It referred to other poets whom the speaker scorned, trivial or unworthy poets whom he did not wish to resemble. ${ }^{3}$

Paden notes that trobador is first found in Marcabru's "Lo vers comens can vei del fau" (PC $293 \cdot 33,1.7)$. In this song, written in the early II30s, Marcabru describes his competition as trobador, people who create petty, silly, or muddled compositions. ${ }^{4}$ Later in his career, Marcabru

2. As Bond observed, "William himself prized and praised above all his formal technique, and twice directly addresses it" (2OI7: 12O).

3. Giuseppe Noto has studied the relation between the terms joglar, which he finds to refer to a recognized group of people with a certain livelihood (performing songs), and trobador, which he finds to refer to one who composes poetic songs, but not for a living (r998).

4. Rossi suggests that Marcabru is targeting Cercamon with these words (2OO9: 2O-22). 
will again inveigh against trobador:

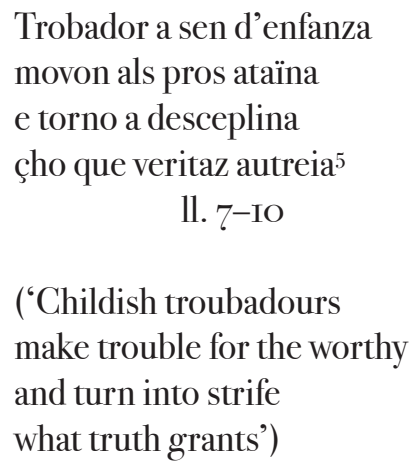

(“Per savi teing ses doptanza”, PC 293.37, tr. Simon Gaunt et al. ed. 2000)

While he does not call these dubious trobadors his predecessors nor attach them to the creation of Occitan lyric, there is clearly, even at this relatively early date in the history of Occitan lyric, a recognition of quality and of aesthetic history.

Regardless of his own disdain for trobadors, Marcabru did explain that he had trained at "the school of Cercamon", words that point to a different founding father. This school of Cercamon is certainly implied in Marcabru's vida as presented in manuscript $A^{6}$, which relates "Apres estet tant ab un trobador qui avia nom Cercamon" ("Afterwards he stayed with a troubadour named Cercamon', Gaunt et al. ed. 2000: 37), though Simon Gaunt et al. state that "It is not possible to confirm the notion that Marcabru served a period of poetic apprenticeship with Cercamon" (2000: I).

Even though this vida credits Marcabru with having worked with Cercamon, another vida, found in manuscript $K,{ }^{7}$ gives Marcabru more mythic power, observing: "Trobaire fo dels premiers c'om se recort" ('He was one of the first troubadours that we remember', Boutière-Schutz ed. I964: Io). The language of the vida demonstrates that the job title of troubadour had become a positive by the thirteenth century (see Paden 20I9: passim). The author of this second vida places Marcabru chronologically at the beginning of the literary history, ignoring Cercamon and Guilhem IX. For the mid-thirteenth century author of this vida, Marcabru has pre-eminence over his twelfth-century contemporaries. A rubric in manuscript $R^{8}$, copied slightly later, takes things one step further, saying of the lyricist, "Marcabru, que fo lo premier trobador que fos" ("Marcabru, who was the first troubadour ever', Boutière-Schutz ed. i964: II). We should be careful, however, in how much authority we give to the vidas; it is possible that the author of the vida is actually implying that Marcabru was the first poet to call himself a trobador, though we know he vehemently rejected that job description (see Paden 2OI9: I5).

There exists another potential "progenitor", Eble II of Ventadorn (Io86-II55) (PC I30). Writing in the second half of the twelfth century, Geoffroy, prior of Vigeois (†I84), described Eble in these terms: "Ebolus ... erat valde gratiosus in cantilenis" (Recueil des historiens 1877: 445); "usque ad

5. On the date, II $5^{2-54}$ (?), see Gaunt et al. ed. 2000: 465 , the only attempt to date this poem cited by BEdT.

6. $A$ = Rome, Bibl. Vat. Lat. 5232, late thirteenth or early fourteenth century (Zufferey 1987: 64; Lombardi-Careri I998: г9).

7. $K$ = Paris, B.n.F. fr. ı2473, late thirteenth or early fourteenth century, Italian hand (Zufferey I987: 69; Meliga 200I: I29).

8. $R=$ Paris, B.n.F. fr. 22543 , composed in the first quarter of the fourteenth century in the Toulousain (Zufferey I987: $\left.130, \mathrm{I}^{2}\right)$. 
senectam alacritatis carmina dilexit" (Recueil des historiens i877: 424): 'Eble the singer gave a great deal of pleasure with his songs'; 'he loved songs of joy into his old age'. ${ }^{9}$ For years scholars have believed that none of his compositions had survived, ${ }^{\text {IO }}$ though Luciano Rossi has recently suggested that songs attributed to Cercamon may have been composed by Eble (Rossi ed. 67-70; Saverio

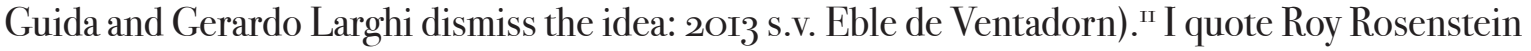
on this subject: "It seems everyone wants to find the lost Ebles and is stealing from Peter to pay Paul” (2018b). While Cercamon is likely a contemporary of Eble, there is no irrefutable reason to assume poetry attributed to Cercamon was composed by the nobleman from Ventadorn, described by François Pirot as "énigmatique" (1973: 647n). So the myth of Eble as a founder of Occitan lyric, while tempting, is unsupported, beyond the single line in a Latin chronicle.

While we cannot call him a founder, a number of troubadours recognized Eble as a patron and/or model, most notably Bernart de Ventadorn, who mentions a "school of Eble" in "Lo tems vai e ven e vire" $\left(\mathrm{PC}_{70} \mathrm{O}, 3 \mathrm{O}\right)$ :

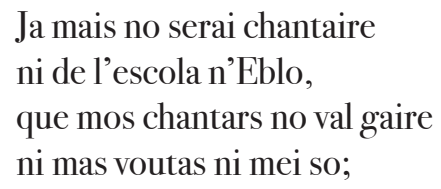

('I will nevermore be a singer nor of the school of Sir Eble, for my song has no value neither my lyrics nor my melody')

Bernart claims not to be worthy of his master. Luciano Rossi insists on this relationship (2009: 49), "Le maître ne peut être qu'Eble". Roy Rosenstein has argued that Jaufre Rudel also trained at the school of Eble, which Rosenstein calls "la seule école de chant, la seule école vernaculaire contemporaine dans la région des troubadours" (I988: I3). ${ }^{12}$ Marcabru also implies a school or poetic practice tied to Eble in "L'iverns vai e.l temps s'aizina" (PC 293,3I): "Ja non farai mai plevina, / ieu, per la troba n'Eblo" (1l. 73-74) ('I will nevermore make a pledge on behalf of the compositions [alt. poetic style/poetic practice] of Sir Eble', tr. Gaunt et al. ed. 2000). ${ }^{13}$ Vincent Pollina understands "L'iverns vai e.l temps s'aizina" as a "repudiation of Lord Eblo (...) a disavowal of a literary father figure" (I99I: IO7).

Lastly, Guerau de Cabrera (fl. II 45-II70) speaks of Eble in his ensenhamen, Cabra joglar (PC

9. The Index rerum of the Recueil des historiens offers this summary: "Ebolus II, Vicecomes Ventadorensis, cognomento Cantator, frater Petri de Petra-Bufferia ex Almode matre, usque ad senectam alacritatis carmina dilexit (...) c. adeptus suis cantilenis Guillelmi VII Comitis Pictav. familiaritatem, cùm strophis se mutuò circumvenire studerent" (Recueil des historiens I877: 894 s.v. Ebolus II).

IO. As Vincent Pollina observed, "It is one of the great ironies of the manuscript tradition that none of the existing chansonniers attributes to [Eble] any of the songs preserved therein” (I99I: IоI). See Pirot 1973: 657n for a careful summation of the several attempts to assign attribution, up to roughly I973.

II. If Cercamon mentions Eble in his planh for Guilhem X, "Lo planh comenz iradamen" (PC II2,2a), does it make sense that Cercamon is a nom de plume for Eble? Rossi thinks Cercamon is sending the work to himself (2009: $\left.3^{6}\right)$ and develops this idea in detail (2009: 67-70).

I2. Rosenstein argues that Jaufre Rudel is at the foundation of the troubadour tradition since he sings of an amor de lonh as opposed to the physical love celebrated by Guilhem IX (20I9), though Rosenstein has also written, "[the Count of Poitiers] had set the standard for not only vernacular love poetry in general but specifically for the inaccessibility topos that Jaufre popularized with his distant love" (20I8a: IOI).

I3. Ruth Harvey understands this line as speaking of Marcabru's "moral disapproval", of Eble and his followers who fail to distinguish between love and lust (I989: 30). 
242a.I). One interest of this pedagogical text is that the author lists all the genres and literary themes a good performer must know. Guerau certainly implies that Eble de Ventadorn is a poet, perhaps with skills on a par with those of Jaufre Rudel and Marcabru:

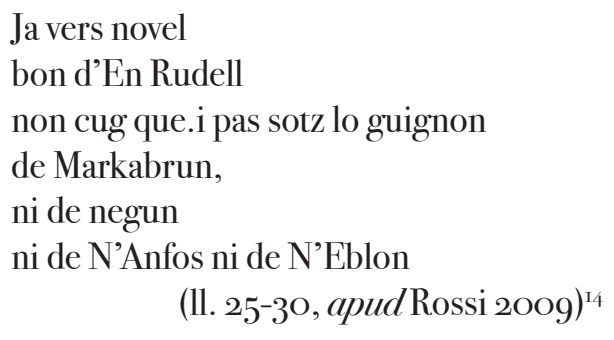

('I don't think that a good vers novel of Sir Rudel ever passes under your moustache [out of your mouth], nor one of Marcabru, nor of anyone, nor of Anfos nor of Eble')

Luciano Rossi concludes, "L'escola n'Eblo (...) a éduqué à la poésie les chantadors et les joglars les plus habiles" (2009: 5I), and, more significantly for my thesis: "Il faut attribuer à Cercamon la fondation d'un vrai canon 'courtois,' définissant pour la première fois les topoi constitutifs de la fin'Amors" (2OO9: IO3). Rossi is not seeking to create a foundation myth, but his conclusions contribute to the mythology of Eble as the founder of Occitan lyric.

\section{Ucde Saint Circ and the vidas}

I have already evoked the vidas, semi-fictional biographies of troubadour singer/poets. One opinion, not universally held, is that these texts, that is, vidas or lives, were collected or composed largely by thirteenth-century troubadour Uc de Saint Circ, who built on material he had accumulated early in his career (see Elizabeth Wilson Poe I99o and, following her, Burgwinkle 1997). ${ }^{15}$ His own vida reports, "Gran ren anparet de l'autrui saber e voluntiers l'enseingnet ad autrui”" ('He learned a lot of the wisdom of others and taught it willingly to others', Boutière-Schutz I964: 240). Importantly, while supposedly training in Montpellier to become a cleric, instead, Uc was learning music and lyric composition, along with "e.ls faich e.ls dich dels valens homes et de la valens domnas que eron al mon, ni eron estat" ("the deeds and words of worthy men and women who were in the world and who had been', Boutière-Schutz I964: 239). These are the lines that allow Bill Burgwinkle to report that Uc "had the reputation of being the 'historian' of the troubadour tradition” (I997: I2I). "As poet, biographer, literary historian and mythographer, Uc must be accorded his rightful place as the 'inventor' (trobador) of 'troubadour poetry' and the ideological trappings with which it came to be associated" (Burgwinkle I993: 348-349).

Though Burgwinkle calls Uc a mythographer, Burgwinkle's arguments present Uc not as playing with foundation myths so much as creating the myth of the poet and his role in society. For example, we have seen the idea of a school or a following in the foundation myths discussed so far. Uc uses the

I4. François Pirot offered a slightly different text $($ I972, 547): "Ja vers novel / bon d'En Rudell / non cug que·t pas sotz lo guingnon, / de Markabrun, / ni de negun / ni d’En Anfos ni d’En Eblon (ll. 25-3o).

I5. Uc de Saint Circ is, of course, not the sole author of vidas; we know that Miquel de la Tor composed the biography of Peire Cardenal (Boutière-Schutz I964: 335-336) and that the vidas in manuscript P, Florence Biblioteca Laurenziana XVI, 42 (completed in I3IO) may be by a different author (Boutière-Schutz I964: xix). 
term "school", escola, only once, in the vida for Guiraut de Bornelh (see Corradini Bozzi I982-87: s.v. escola), where Uc relates, "E la soa vida si era aitals que tot l'invern estava en escola et aprendia letras, e tota la estat anava per cortz e menava ab se dos cantadors que cantavon las soas chansons" ('And his life was such that all winter he was in school teaching letters and all summer he went to courts and brought with him two singers who sang his songs', Boutière-Schultz eds. I964: 39). In this passage, Uc is simply describing the employment of one troubadour, not setting Guiraut as a founder, even of the school at which he taught.

Significant for my argument is the reality that Uc used as a model for the vidas, the Latin accessus, presenting Occitan lyricists in the same format and with the same dignity as their Latin forebears (see chapter 6 in Meneghetti I984; the Italian scholar presents the modelling well). Uc's observations were not only chronological, as we observed in the case of Marcabru, but also aesthetic. For example, he gives Peire d'Alvernha critical approbation: Peire "fo lo premiers bons trobaire que fon outra mon"I6 ( 'was the first good troubadour who lived beyond the hills', Boutière-Schultz ed. I964: 263), implying that Peire's predecessors were mediocre.

I would nuance Burgwinkle's description of Uc as the inventor of troubadour poetry, not so much because Uc created the myth, but rather because he took the traditions of troubadour lyric to a new place. Burgwinkle states, "The uniquely cynical vision of Uc de Saint Circ sent the lyric spinning in another direction" (1997: I45), one that might not necessarily be followed by a subsequent generation in Occitania.

\section{Consistory of Gay Science}

In the fourteenth century, a group of Toulouse citizens sought to preserve the traditions of Occitan lyric. In the blunt words of Robert Lafont, "Capitale par le langage, Toulouse avait voulu l'être au début du XIVe siècle. Pour cela avait été créée l'institution du Gai Savoir et écrites les Leys d'amors" (I970: 19). As recounted in fourteenth-century documents, seven men had been meeting regularly to discuss their own poetry. Seeking to expand their audience and to increase participation, they launched a poetic competition at the end of $\mathrm{I}_{32} 3$, calling for a May I324 gathering of poets (Laura Kendrick 2008 offers a good retelling of the historical foundation).

The Toulouse burghers founded what came to be called a "Consistory of Gay Science", "consistory" in the sense of "gathering, meeting". ${ }^{17}$ After several years of competition, they asked Guilhem Molinier ${ }^{18}$ to compose a Leys d'amors, a handbook or rulebook, in order to perpetuate poetry in their community. In this work, Guilhem presented rules and models for poetic composition (though his effort is of uneven utility for medieval poets and modern scholars, see Pfeffer I986) and helped create a new foundation myth. In this case, the foundation myth emerges from a largely bourgeois group of amateur poets who seek to justify their existence. They may also have sought to elevate their efforts and the status of their city and its language.

The Leys d'amors exists in multiple versions, one long in prose, composed between I324 and I335

I6. The precise meaning of the last two words is subject to debate, see Boutière-Schultz ed. I964: 265 n.

I7. Anglade notes that the founders of the Consistory were probably using the University of Toulouse as a model for the structures and rewards of their corporation (Anglade ed. I9ı9: 4, 33-37, citing Pio Rajna I927); as Marisa Galvez observes, "The Consistory borrows both the governing and scholastic procedures of the University in order to ensure the institution's legitimacy" (2OII: 44). Passerat (2000: 450) understands this development as occurring more slowly than does Galvez.

I8. Guilhem Molinier reports that he was assisted by Bortholmieu Marc (Anglade ed. I9I9: I, I4). 
-it might be considered a good first draft, in five books (often referred to as Las Flors, I will call this version Leys A, Bibliothèque municipale de Toulouse 2884, edited by Adolphe-Félix GatienArnoult [I84I]; Brunel 1935: \#263). ${ }^{\text {.9 }}$ It was followed by a second, shorter, prose version, in three books, composed between I355 and I356, when this version was promulgated (Anglade ed. I9I9: 4, 3I and 4, I26) - we might dub this a final version (Leys $C$, Bibliothèque municipale de Toulouse 2883, Anglade ed. 1919; Brunel 1935: $\#_{264}$ ). There is also a version in octosyllabic couplets, entitled the Flors del gay saber (Leys B, ${ }_{7} 6 \mathrm{I} 6$ lines), composed during the second quarter of the fourteenth century, extant in two manuscripts (Barcelona, Biblioteca de Catalunya 239 - Brunel 1935: \# 37 and Madrid, Biblioteca nacional r3405, Anglade ed. r926; Brunel r935: \#45). ${ }^{20}$

In the 1356 prose version $($ Leys $C)$, the author relates this foundation story:

En lo temps passat, foron en la reyal nobla ciutat de Tholoza.VII. valen, savi, subtil e discret senhor, liqual hagro bon dezirier e gran affectio de trobar aquesta nobbla, excellen, meravilhoza e vertuoza dona Sciensa, per que lor des e lor aministres lo gay saber de dictar, per saber far bos dictatz en romans

(Anglade ed. r9I9: I, 8)

('In days of yore, there were in the royal, noble city of Toulouse, seven distinguished, wise, clever individuals of discretion, who had the desire and wish to find/sing about this noble, excellent, marvelous and virtuous lady Knowledge, so that she would give them and furnish them with gay saber - pleasant wisdom - for composing good words in the Occitan language')

Then follows what can be dubbed a call for papers, reportedly issued in I323, ${ }^{2 \mathrm{I}}$ less a call than an invitation to compete for a prize to be awarded at the beginning of May I324, a violet made of gold (“una violeta / de fin aur, en senhal d'onor", 'a violet of fine gold, as a sign of honor', Anglade ed. I9I9: I, II). However, the judges recognized that they were playing without a rulebook, which they asked Guilhem to assemble: "Quar li dit.VII. senhor jutjavan ses ley e ses reglas (...) Et adonc comezero de bocca a mestre Guilhem Molinier, savi en dreg, que el fes e compiles las ditas reglas" ('For the said seven men were judging without rules or regulations (...) And so they requested, orally, of Master Guilhem Molinier, wise in law, that he make and compile said rules', Anglade ed. I9I9: I, I4-I5), rules that would be called Leys d'amors, intended to be public: "per los savis e discretz mantenedors del Gai Saber de l'an .M.CCC.LV. (...) ordenero que degus dictatz no fos sagelatz" ("the wise and discrete counselors of Gay Saber of the year I355 ordains that no poetry will be under seal', Anglade ed. I9I9: I, I5; see also Anglade ed. I9I9: 4, 25).

I9. A version of the Leys in at least five books certainly existed by I34I, when it was mentioned by Joan de Castelnou (Anglade ed. 1919: 4 I22). There exists a slightly abbreviated and Catalanized prose version of Leys A in Barcelona (Archivo del la Corona de Aragón, S. Cugat del Vallés ı3, Brunel r935: \#33) (Zufferey r98ı: xxxv). See also Fedi i999. Each editor of the Leys has set his own set of sigla (see Zufferey I981: xxxvii); I have dubbed the versions A, B, and C, based on chronology, as did Georges Passerat (2000: 452-53).

20. Chabaneau posited this development, "L'oeuvre de Molinier a passé évidemment par trois états: I rédaction antérieure à I34I, aujourd'hui perdue (?), \& sur laquelle se fondent les deux ouvrages de [Joan de] Castelnou [Compendi, and commentary to Cornet's Doctrinal de trobar] (...) $2^{\circ}$ notre ms. B, qui développe, complète \& ordonne, à l'usage du public, cette première rédaction [Gatien-Arnoult I84I]; $3^{\circ}$ notre ms. A, à la fois exposé historique \& recueil de documents, de lois \& de préceptes, à l’usage particulier des membres du gai consistoire [Anglade ed. I9I9]” (I885: I84n).

2I. "Donadas foron el vergier / Del dit [dic] loc, al pe d'un laurier, / El barri de las Augustinas / De Tholoza, nostras vezinas. / Dimars, quar no.s poc far enans, / Aprop la festa de Totz Santz, [Sans] / En l'an de l Encarnacio / De Crist, nostra redemptio, / M. e .CCC. e .XX. e tres" (Anglade ed. I9I9: I, I2; readings in square brackets from Chabaneau I885: I83). 
In his second book of Leys $C$, Guilhem explains why he composed the Leys:

Aquestas Leys fam per so qu'era dispers, rescost, escur, compilar, manifestar e declarar e may per jutjar, punir e remunerar, so es gazardonar, et per refrenar los dezonests movemens e vas deziriers dels fols enamoratz

(fo 66r, Anglade ed. I919: 2, I4)

('We make these rules to compile, publicize and declare what had been dispersed, hidden and obscure, and (even) more to judge, punish and remunerate, that is to reward, and to restrain dishonest movements and the desires of foolish lovers')

This statement references only contemporary poets, with no explicit reminder of those who had come before.

Guilhem Molinier's earlier prose text, Leys A, made clear that he and the members of the Consistory saw themselves in an extended tradition; they sought, "De far leys d'amors, segon los bos anticz trobadors" ("to make the laws of love (i.e. poetry), according to the good troubadours of olden days', Gatien-Arnoult I84I: I, 2; see Anglade ed. I9I9: 4, 90-9I). With this idea in mind, Guilhem cited two lines of Arnaut Daniel's sestina, “Lo ferm voler qu'el cor m’intra” (PC 29,I4) with attribution in Leys A (Gatien-Arnoult I84I: 3, 330), though Arnaut does not appear by name in the subsequent versions. As Catherine Leglu has posited, Toulousains "had a sense of regional identity embedded in history" (2OI6: I44), and references such as this reflect that sentiment. Though Guilhem names no names in his introduction, though his examples are, in truth, only rarely from the twelfth century, he did see his work in a tradition that went back in time. ${ }^{22}$

In the earliest version $(\operatorname{Leys} A)$ and in the verse text $($ Leys $B)$, we have a longer direct quotation of an earlier poet, when Guilhem cites twelfth-century Raimbaut de Vaqueiras by name, before using the troubadour's renowned multilingual lyric, "Eras quan vey verdeyar" (PC 392,4$)$ as an example of the cobla partida. In the first version, the stanza is introduced with these words, "Cobla partida es can conte dos o motz diverses lengatges segon quom pot vezer en esta cobla que fe en Riambaut [sic]" ("A cobla partida is when there are two or more languages as you can see in this stanza by Raimbaut") (Gatien-Arnoult I84I: I, 334). The tornada of "Eras quan vey verdeyar" follows. In Leys $B$, the verse version, the example is presented in this fashion:

Cobla partida veiats ara,

la qal mot lengatges empara;

fatxa fon per En Rambaut,

un Cavaller pros ez asaut.

De cobla partida

Bells Cavallers, tan es grans

le vostre grans senyoratges

quez un jorn me n'es mocho.

Oy me, laso! que faro?

Si cella que j'ay pus chiera

22. Anglade says that Guilhem cites a line of Peire Vidal's without attribution and that he knows the names of Arnaut Daniel and Raimbaut de Vaqueiras (г9г9: 2, 9I). In a later article, Anglade posits that Guilhem knew the works of numerous troubadours, including Giraut de Bornelh and those cited in Matfre Ermengaud's Breviari d'amor (Anglade I927: 383). Anglade mentions Guilhem's quoting of at least two other poets, Rigaut de Berbezilh and, outside of Occitan, Thibaut de Champagne (cited several times in the Breviari, see Ricketts I976: 32 ). Each of these poets has an incipit cited by Guilhem (Anglade I9I7-I8: 269-70). 
Me tua no say por quoi.

Ma dauna, he que diot a bos

Ni peu cap sancta Qiteyra,

Lo coraso m'avetz touto

E mou dousamen furtado.

(ll. 3047-3053, as published by Ricketts 2005;

compare Anglade ed. 1926: 6o ll. 305-3060)

('You will now see about the cobla partida, which involves using multiple languages: One was composed by Sir

Raimbaut de Vaqueiras, a worthy and savvy knight. Of the

cobla partida. Fair Knight, so great is your great lordship that

one day I cry a lot. Alas, I despair of what to do, if she whom

I hold most dear kills me, though I don't know why. My lady, source of all good things and by the head of Saint Quiteria,

you have taken my heart and stolen my sweetness'). ${ }^{23}$

The shorter, final version (Leys $C$ ) also cites this stanza as an example of the cobla partida, but without attribution. ${ }^{24}$ In truth, however, as I myself noted, "Guilhem Molinier (...) preferred to describe verses of his own creation than to comment on the lyrics of his predecessors" (Pfeffer i986: 209).

Georges Passerat described Guilhem Molinier as the "artisan d'un renouveau de l'occitan" (2000: 466); Sarah Kay has noted that $L e y s ~ C$, specifically, has a number of elements that mark it as a new beginning (20I3: I79):

The use of troubadour quotations is transformed (...) All the excerpts from the twelfth and early thirteenth-century poets are either dropped (...) or rendered anonymous by eliminating the attributions (...). Consequently, the only troubadours referred to by name in this new redaction are At de Mons and Molinier himself (...). Unlike all the earlier treatises, including its own earlier incarnation, this new version of the Leys is not about continuing the troubadour tradition. Instead, it erases their names and begins again, in Toulouse, in the late thirteenth century.

A new, fourteenth-century myth is established, allowing the Consistory to "substitut[e] linguistic resistance for the religious and political conflicts that lay behind and around it" (Leglu 2OI6: I5O), a myth that establishes Guilhem Molinier and his colleagues as the new founders.

It must be added that at some time between $\mathrm{I}_{32} 3$, date of the call for submissions, and $135^{6}$, date of the final version of the Leys (Leys $C$ ), the governing body of Toulouse, the Capitouls, became financial sponsors of the competition, allowing it to take place in City Hall and paying the cost of the prize, the gold violet (see Gélis I9I2: 22 and 35, ${ }^{25}$ Kendrick 2008: 23).

23. The text of Raimbaut's concluding cobla, which mixes all the languages of his song, is as follows: "Belhs Cavaliers, tant es car / lo vostr' onratz senhoratges / que cada jorno m’esglaio. / Oi me lasso! que farò / si sele que j’ai plus chiere / me tue, ne sai por quoi? / Ma dauna, he que dey bos / ni peu cap santa Quitera, / mon corasso m'avetz treito / e mot gen favlan furtado" ("Fair Knight, so precious to me is your noble sovereignty that each day I am dismayed. Ah me! What shall I do, if she whom I cherish most slays me, I know not why. My lady, by the faith I owe you and by the head of Saint Quiteria, you have wrested my heart from me and stolen it with your most sweet discourse', ed. and trans. Linskill r964: г92-I93).

24. The stanza is introduced with these words: “Cobbla parrtida conte dos o motz diverses langatges, segon qu'on pot vezer en esta cobbla” (Anglade ed. I9I9: 2, I72).

25. "L'idée de la création de la Gaie Science appartient aux sept associés de i334. Eux seuls en eurent l’initiative,' 


\section{The Sixteenth Century}

The story set by Guilhem Molinier appears to have been insufficient in the late fifteenth and early sixteenth century, when Toulouse was moving firmly into the French linguistic orbit. One element in this pivot was the re-establishment of the Consistory under a new name: the Collège d'Art et Science de la Rhétorique. It is not insignificant that the city of Toulouse was creating a foundation myth for itself at roughly the same time (Courouau 2008: 37I; Escudé 20I7: 74-75, I8I). Occitan was being replaced by French; the Consistory turned Collège postulated new rules; a new supporter of the poetic tradition was needed and, ergo, invented - Clémence Isaure. Her creation is a creation myth in itself (see Gélis I9I2: 260-266, summarizing the conclusions of Roschach I896 or Gélis I9I2: 268-269 for another summation of Roschach's argument).

As François de Gélis describes the transformation,

Le Gai Consistoire est devenu le Collège de la Science et Art de Rhétorique, (...) et tout ce qu’on écrit, prose ou vers, appartient désormais à la langue du Nord. On trouve encore, au début du Livre Rouge, quelques échantillons de poésie romane, mais ils disparaissent dans la première moitié du seizième siècle”. (Gélis I9I2: 73)

Jean-François Courouau and Pierre Escudé second the observation that the Livre rouge, begun in I55O and collecting the prize-winning poems composed between I5I3 and I64I, shows the movement away from Occitan. The last Occitan lyric included dates from I5I3 (Courouau 2008: 383-384; Escudé 2017: 74n). The new College, now functioning in French rather than Occitan, ${ }^{26}$ was ready for a new founding story, of a different sort; one was soon created.

A woman by the name of Clémence is documented in late fifteenth-century Toulouse - her name shows up in the accounts of the city for I489, where she appears in these terms (Gélis I9I2: I9I-I92): "Item e pagat a Jacmes Mostier, pintre, per far le pitaffle del portal de la gran porta e le pitaphle de la Dama Clamenssa, come apar per lo mandament que monta $X$ sols" [Item, paid to Jacmes Mostier, painter, to make the banner of the large gate and the banner of Lady Clémence, as seen in the order for ten sous]. François de Gélis interprets this passage as suggesting that Clémence was already associated with the poetic contest known as the Jocs florals or Jeux floraux (as the festive distribution of poetic prizes is called) by the end of the fifteenth century (1912: 192). ${ }^{27}$

The Livre rouge of the Académie des jeux floraux for the years $15^{\mathrm{I}} 3^{-1} 5^{8} 3$ has these words at its opening (Gélis I9I2: 35I):

Ce présent registre des délibérations et autres actes faictes au collège intitulé de l'art et science de la rhétorique, autrement dit de la Gaye Science, fondé en Tholoze par feue Dame Clémence de bonne mémoire, a esté commencé à mettre en oeuvre au moys de mars mil cinq cens cinquante. ${ }^{28}$

Here, Lady Clémence is evoked as a founder of the society. Furthermore, the speeches pronounced during the awards ceremony uniformly praised Lady Clémence, at the same as they demonstrated the linguistic transition of the Jeux floraux - from discourses in Latin (in I487) to speeches in

mais, dès le premier jour, ils s'associèrent avec les Capitouls et convinrent avec ceux-ci de porter les fleurs au compte du budget communal' (Gélis I9I2: 35, his italics).

26. Jean-François Courouau dates the linguistic shift specifically to the years $5_{5}^{\mathrm{I}} 3^{-\mathrm{I}} 5^{\mathrm{I} 9}$; he suggests that Blaise d'Auriol (I475?-I54O), a Mainteneur in I52O, is the likely agent (2008: 384-385).

27. Pio Rajna understands "pitaffle" as referring to text rather than images, thus explaining the relatively low price for the painter's work (I927: 219-220).

28. The Register records the date of $\mathrm{I} 55 \mathrm{O}$ here, but recounts earlier history as well. 


\section{French by $1528 .{ }^{29}$}

In I522-I524, a dispute arose between the Capitouls, who govern the city of Toulouse, and the Mainteneurs of the Jeux floraux..$^{\circ}$ There were charges of money being stolen, the implication being that it was the bequest of Clémence that had been misused. The year of 1524 is important, because this is when a reference (though not the first mention ${ }^{3 \mathrm{r}}$ ) to a last will and testament appears in the vernacular record..$^{32}$ To paraphrase the words of the Capitouls,

Pour l'entretènement de la fondation de dame Clémence, qui a laissé par légat à la Ville lès revenus de la Place de la Pierre, la moitié du Pontanage de la rivière de Garonne, le Pain du Gorp et autres biens qui ne sont ni deniers communs, ni dons ou octrois du Roi, ains patriimoine laissé à la Ville par ladite dame, à la charge de fournir pour les fleurs, etc. (Gélis I9I2: 84)

Four years later, Clémence appears in what had been, up until I527, simply a Latinate speech of thanks. $5_{2} 28$ marks the first appearance of our heroine in the "Sermon des fleurs" presented by Antoine Vinhalibus (Gélis I9I2: IO4). ${ }^{33}$ This marks the first recognition in poetry of Clémence as patron of the Jeux floraux (Gélis I9I2: 198). ${ }^{34}$

29. “L'Oraison à Dame Clémence, respectée par le temps et la tradition, est devenue l'Eloge de Clémence Isaure, qu'on prononce encore aujourd'hui, dans les mêmes circonstances et à la même date. Mais tandis que l'orateur moderne peut varier son langage et donner libre cours à sa fantaisie, le poête d'autrefois devait, par respect pour la forme et les souvenirs classiques, parler toujours en latin” (Gélis ı1ı: 78).

30. Gélis offers these details on local politics (І9ı2: 80n): “On a parlé aussi de la rivalité qui naquit entre les Jeux floraux et l’Université, mais on l’a fort exagérée. Les Docteurs el Bacheliers du Gai-Savoir ne pouvaient logiquement rompre en visière avec des confrères auxquels ils avaient emprunté leurs titres et leurs statuts, et même à l'époque la plus intransigeante de notre histoire, lorsque les magistrats parlementaires eurent fait du Collège de Rhétorique leur domaine à peu près exclusif où vit les Docteurs-régents de l'Université s'asseoir au milieu d'eux. La véritable querelle était ailleurs: entre le pouvoir consenti el le pouvoir électif, entre les hommes chargés d'appliquer les lois d'intérêt général et les hommes chargés de défendre les intérêts particuliers de la cité. Ces deux autorités qui se battent ont, malheureusement, pris le terrain de la Gaie Science pour lice et pour champ clos”.

3I. Jean-François Courouau (2008: $3^{87}$ ) points to Guillaume Benoît's I523 (new style) publication where we can read: "Ubi glosa dicit quòd etiam pro ludis in civitate anno quolibet faciendis relinqui potest, prout illustris mulier illa fecit domina Clementia ditissima civis Tholosana: quae ad juvenes incitandum ornatè cultoque sermone loqui, nonnullos reliquit civitati redditus, et quibus anno quolibet tres fiunt argentei flores scilicet anglentina, violeta, \& gaudium deaurata [sic], tertia die Maii, in capitolio urbis praesente senatu tribus juvenibus per cancellarium artis illius magistrorum conferendum, qui subtilius die prima mensis praedicti \& ornatius dictaverint. Qui demum magno cum equitatu \& pompa die ascensionis dominicæ vehuntur per civitatem jocundè cum triumpho \& ingenti gaudio. Ex quo plures ad bene recteque loquendum, scribendum, \& legendum vires susceperunt" I cite a later edition (Benoît I544: Secunda pars, Tractatus fideicommissariae substitutione, §I2 f. 7IV.).

32. Ernest Roschach presents this text (Archives de la Ville, BB I58, 7I), as evidence of the evocation of Clémence in the early I520’s (I896: 234): “De par Messieurs de Capitolz, Chancellier, Conseillers et Mainteneurs de la Gaye Science. L'on faict assavoir à toute manière de gens tant escolliers, bourgeois, marchans et aultres, que, le premier jour du moys de may prochain venant, qui vouldrait soy trouver à la Maison Commune de Tholose - ainsin qu' est de bonne coustume, là où funda Dame Clémence dont Dieu ayt l'ame et voulut que l'on donnast trois fleurs d'or et d'argent compossées au mieulx disant touchant l'art de la Rhetorique, mais que l'on n'y mecte poinct d'infamyté ny villainie en quelque langage que ce soit, - sera receu. Et pour ce venez en paix et sans noyse faire. XVIIe jour d'avril mil cinq cens XXIIII. SALAMONIS”. This document evokes the foundation by Lady Clémence of the various prizes awarded at the Jeux floraux, specifically the flowers sculpted in precious metals (awarded to this day). However, Clémence’s testamentary document has remained invisible (see Boyer 20IO: 32). Following Gélis and others, I would suggest that such a document never existed.

33. Gélis supports this statement with this documentation: "Lagane avait déjà relevé cette note dans les comptes de l'Hôtel de ville: 'Payé à Antoine Vinhalibus, bachelier es droits, pour avoir fait le Sermon de Dame Clémence, le jour des Fleurs, qui était le jour de Sainte-Croix: 2 livres.' (Mandement du 26 mai I528)”. See also Gélis I9I2: I99 n. I.

34. According to Gélis, "A partir de I54O, il [le Chancelier des Jeux floraux] ajoute cette formule: 'car telle est la 
The myth of Clémence was firmly in place, and she had acquired the family name of Isaure (Gélis I9I2: 234). By I540, the leaders of the Consistory evoked Clémence in order to obtain funds from the city (see Gélis I9ı2: II5n). As François de Gélis reports (ı912: 84):

Les Mainteneurs de 1540 invoquèrent le testament d'une certaine dame Clémence, de mémoire incertaine et d'existence problématique. Elle avait, disaient-ils, légué de grands biens à la Ville, à charge pour celle-ci de célébrer annuellement la Fête des fleurs et de pourvoir à toutes les dépenses qui en résulteraient.

At roughly the same, time, that is, by the $154 \mathrm{OS}$ and $\mathrm{I} 55 \mathrm{OS}$, the church of Notre Dame de la Daurade had become associated with Lady Clémence (Gélis I9I2: 208). ${ }^{35}$ In I549, a gisant, probably that of Bertrande Ysalguier, who had died in I348, was transported from the church of Notre Dame de la Daurade to the Toulouse city hall (see Roschach I892: I3I-I34).${ }^{36}$ Bertrande became a physical representation of Clémence, celebrated in verse at the time of the move.

The Wars of Religion were significant factors in Toulouse history, interrupting the ceremonies of the Jeux floraux. In I573, prizes were again awarded; the reports of the meeting of this year mentioned, for the first time, a Lady Clémence de Ysalguy, combining the first name we have followed here with the family name of Ysalguier, i.e. that of Bertrande. It is possible that Bertrande, the source of the gisant, was related to Bartholi Ysalguier, one of the judges of the fourteenthcentury Consistory. ${ }^{37}$

By the second half of the sixteenth century, the myth was set. I would add that at no point in the growth of the Clémence myth were any twelfth- or thirteenth-century troubadours evoked; needed was a more recent and more firmly local, founding story. Moreover, the myth of major donor, in the person of Clémence, is a marked departure from the earlier founding tales, predicated on individual poets. In the economy of sixteenth century Toulouse, literature needed funding, so a generous benefactor - who could serve as model for others - was invented.

One additional explanation of the myth creation, in the case of Clémence Isaure, is that she provided a visual representation of Occitan lyric, an image that could be copied and distributed, posted in public places. Clémence adorns a good number of public buildings in Toulouse to this day; a street in Toulouse has been named for her, as have any number of institutions..$^{8}$

We cannot know the motivations of those who invoked Clémence Isaure as the individual who endowed the Consistory with funds to award prizes for poetry. It seems certain that no woman by this name ever left such a legacy in her will; we know, too, that not all Toulousains accepted the myth. For example, Guillaume Catel (I560-I626) affirms, in his Mémoire de l'histoire du Languedoc, that “jamais Dame Clémence que l’on dit fondatrice de ces Jeux n’a esté au monde” (I633: 398).

Volonté de dame Clémence, de bonne mémoire, el la disposition inscrite dans son testament.' Et l'on comprend tout ce que ce testament que personne n'a jamais vu, mais que les Mainteneurs invoquent avec une gratitude émue, ajoute de force à leur réquisition" (I9I2: 74).

35. Jean Bodin appears to be the first to designate the church as the site of her tomb, echoing popular tradition (Gélis I9I2: 208).

36. See the description in Gélis r9ı2: 236.

37. Zufferey records an Odet Izalguier who may have been a mainteneur of the Jeux floraux in I46I (I98I: 39) and a Peire Izalguier who served as a mainteneur in I460 (I98I: $4 \mathrm{I})$. Their dates align neither with the century of Bertrande nor with period when Clémence acquired a family name.

38. Toulouse boasts a daycare center, a middle school, a high school, and an addiction treatment center all named for Clémence, according to Google Maps <http://tinyurl.com/y3gugvsj> (accessed 24-O2-2OI9); there is also a médiathèque in the Toulouse suburb of Villeneuve-Tolosane that carries her name. Her image has also been subverted by contemporary Occitan authors, such as Joan Bodon, who turned her into a prostitute in his lyric "Tolosa" (I975). 


\section{Jean de Nostredame $\left(15^{22--76 / 7)}\right.$}

$\mathrm{W}$ hile I am not convinced that Jean de Nostredame sought explicitly to create a foundation myth for troubadour lyric, his Vies des plus celèbres et anciens poètes provençaux can be interpreted in that fashion and certainly was used to that end. ${ }^{39}$ The author claimed to have written his history of regional poetry to keep alive the names of authors and families now forgotten,

J'ay eu un singulier et (comme je croy) louable desir de les communiquer et mettre en lumiere (...) à ce que les noms, familles et qualités de tels excellens poëtes soyent cognus et espandus tant plus loin et en divers endroits, esquels leur renommée pourroit estre parvenue. (Chabaneau-Anglade ed. I9I3: 3-4)

He reminds his readers that "nostre Provence" was called "la boutiqua dels Trobadours (Chabaneau-Anglade ed. I9I3: 7); readers today know that Nostredame sought to glorify his native region by incorporating into it any and all troubadours he could.

Nostredame recognized the role patronage played in the survival of troubadour lyric, "defaillans des Mecenas, defaillirent aussi les poëtes" (Chabaneau-Anglade ed. I9I3: 8), a line that may also have been a pitch for himself. He reported his source as a manuscript in the hands of the Count of Sault (Chabaneau-Anglade ed. I9I3: 9), a volume no longer extant, though Camille Chabaneau and Joseph Anglade succeeded in reconstructing it in their "Essai de reconstitution" (I9II). Nostredame described the evolution of Provençal as a serious decline "nostre langue provensalle s'est tellement avallée et embastardie que à peine est elle de nous" (Chabaneau-Anglade ed. I9I3: I2). In an effort to save the language and its literature, Nostredame reports that he had "mis les vies de nos poëtes provensaux en avant, lesquelles m’ont semblé dignes de n'estre ignorées” (Chabaneau-Anglade ed. I9I3: I3).

Nostredame states that lyric composition in Occitan began in II62 (Chabaneau-Anglade ed. I9I3: 8), a date whose choice is hard to explain, unless related to the first poet in his collection, Jaufre Rudel ( $\uparrow$ circa II47), whom the Renaissance author makes a contemporary of Geoffrey II of Brittany (II58-II86) (Chabaneau-Anglade ed. I9I3: I5-I8). As part of his effort to adopt as Provençaux as many troubadours as possible, Nostredame makes Jaufre lord of Blieux en Provence (Alpes-deHaute-Provence), rather than of Blaye (Gironde) near the Atlantic coast. The sixteenth-century author presents a poet who found refuge at Sault (Vaucluse), where he met Geoffrey of Brittany, who was passing through the neighborhood. Geoffrey took Jaufre into his retinue, but then Jaufre heard of the countess of Tripoli; now Nostredame incorporates elements found in Jaufre's vida, that semi-fictional document, to relate the end of his life. Amplifying his material, Nostredame tells us that the countess of Tripoli had a sepulcher made for Jaufre, complete with an Arabic inscription

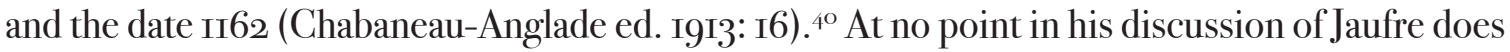
Nostredame say explicitly that Jaufre was the first troubadour, though Roy Rosenstein states that the sixteenth-century author "placed Jaufre Rudel at the onset of the troubadour tradition" (2or8a: I03). We can make this inference only because Jaufre is the first poet discussed in the Vies.

If we accept Nostredame's statement that his raw material came, at least in part, from the lost Chansonnier de Sault, then we must ask where Jaufre appeared in that songbook. According to Camille Chabaneau and Joseph Anglade, the manuscript opened, folio I, with lyrics by Giraut de

39. César de Nostredame (I553-I629), Jean de Nostredame’s nephew, worked consciously to establish a filiation between the medieval troubadours and his own period in his L'Histoire et chronique de Provence, published in I6I4 (see Escudé 2OI7, 229).

40. The edition reads “ $5_{5} 62$ ” with a note (I6n) correcting the printer’s error. 
Bornelh (I9II: 252), who is very often the first poet in troubadour song collections. Jaufre's position in the reconstructed manuscript would have been on folio Io8 (Chabaneau and Anglade I9II: 267), well into the anthology. Nostredame pulled Jaufre out of the middle to put him first, a clear indication of Nostredame's interest in the poet.

The second individual described by Nostredame is Frederick I Barbarossa (Chabaneau-Anglade ed. I9I3: 19-2O), whose presence in the Vies is somewhat curious. We read his praises and a description of how he acquired lands in Provence for the Empire in II62 (Chabaneau-Anglade ed. I9I3: 20). In response to "plusieurs beaux chants en langue provensalle", praises sung to him, the emperor responded, according to Nostredame, with gifts and "un epigramme en langue provensale, à la louange de toutes les nations qu'il avoit suivies en ses victoires, auquel epigramme il loue la langue provensale" (Chabaneau-Anglade ed. I9I3: 2O). Then follow ten lines of verse. ${ }^{4 \mathrm{I}}$ Nostredame points his reader to Sainct Cezari (i.e. Uc de Saint Circ), one of his sources for the Vies, and to the Monge des Isles d'Or, an individual scholars now recognize as Nostredame himself. We can safely dismiss Frederick Barbarossa as an Occitan poet; his placement by Nostredame as second individual discussed in the Vies serves to elevate the status of troubadour lyric (and the Occitan language), another element of mythmaking, by making the emperor a poet himself.

\section{Conclusion}

T. o this point, I have considered several foundations and foundation myths for one linguistic and poetic tradition, all from the medieval and Renaissance periods, most often tales based on a founding individual. The question must be asked, why did the Occitan literary heritage need and create, during the Middle Ages and Renaissance, so many foundation stories, real and mythical? I would suggest that what was perceived as the comparatively tenuous literary status of Occitan, against Latin in the early twelfth century, against French in the fourteenth and again in the sixteenth century, explains the repeated efforts to validate Occitan legitimacy and originality. During the fourteenth century, Catherine Leglu reminds us, "Vernacular expression was still presented as something that was subordinate to Latin" (2008: 385). As the anthropologist Bronislaw Malinowski reminds us, "Myth is (...) constantly regenerated; every historical change creates its mythology which is, however, but indirectly related to historical fact" (I954: I46). To this end, early lyricists pointed to noble forebears, such as Eble de Ventadorn, to justify composition in the local vernacular, as opposed to Latin. The fourteenth-century founders of the Consistori del gai saber needed to validate their position as judges of poetry, so they presented a different foundation myth to justify their activities. The fifteenth- and sixteenth-century myth of Clémence Isaure emerged as Toulouse moved firmly into the French linguistic realm, as a means of maintaining linguistic and, more importantly, literary independence by justifying local and long-standing popular support. Jean de Nostredame invoked noble initial poets, one more attempt to glorify the literary and linguistic heritage of Occitan.

Add to this collection of foundation tales the multiple suggested etymologies for the Occitan word for poetic composition, trobar, which gives us the occupational name of troubadour (see Paden 20I9).

James Costa has observed, speaking of Scots language and literary history, that "history is seen

4I. The lyric is not particularly inventive: "Plus my cavalier Frances, / E la donna Catallana, / E l'onrar del Gynoés, / E a cour de Kastellana, / Lou kantar Provensalles, / E la dansa Trivyzana, / E lou corps Aragonnés, / E a parle Julliana, / Las mans e kara d'Anglés / E lou donzel de Thuscana" (Chabaneau-Anglade ed. r9I3: 20). 
as a way to give existence to Scots (...) as well as to legitimise both its presence on the public scene and that cultural movement that foregrounds it" (2009: 6). The same logic holds for Occitan language and literature, from the thirteenth century to the sixteenth. I must add that the creation of foundation myths for Occitan literature has continued into the present, seen, inter alia, in the works of Antoine Fabre d'Olivet (I767-I825), Claude Fauriel (I772-I844) and Robert Lafont (I923-2009).

Every society creates founding mythologies as a means of self-justification in order to rationalize its origins or establish an independent identity. What is interesting about the Occitan case is the number of differing, though not necessarily conflicting mythologies invented over the course of about four hundred years. Each myth served the purpose of defending Occitan lyric and/or language in the face of detractors, real and imagined; each myth offers a different angle from which to observe lyric and the society that enjoyed it.

\section{Acknowledgements}

I must thank Roy Rosenstein (American University in Paris), Rosa María Medina Granda (Universidad de Oviedo), the anonymous readers of Magnificat CLM for their extremely useful comments on this research, and Magnificat CLM s editor, Rosanna Cantavella. 


\section{IO Works Cited}

Anglade, Joseph. I9I7-I8. 'Les Joies du Gai Savoir, recueil de poésies couronées par le Consistoire de la Gaie Science (1324-1484), trans. J.-B. Noulet, intro. Alfred Jeanroy', Annales du Midi, 29-30: $26 \mathrm{I}-73<$ http://links.uv.es/gUUIdaj>

Anglade, Joseph (ed.). r9I9. Las Leys d'amors, manuscrit de l'Académie des Jeux floraux, 4 vols (Toulouse: Edouard Privat)

Anglade, Joseph (ed.). 1926. Las Flors del Gay Saber (Barcelona: Institut d'Estudis Catalans)

Anglade, Joseph. 1927. 'Les Leys d'Amors et Giraut de Borneil', Romania, 53: $3^{8 \mathrm{I}-383}<\underline{\text { http:// }}$ links.uv.es $/ \mathrm{Vl}_{4} \mathrm{~J}$ Ioz $>$

Benoît, Guillaume. Benoît, Guillaume. I544. Repetitio capituli, Raynutius de Testamentis (Lugduni: Antonium Vincentium) < https://tinyurl.com/y382fggn $>$

Bond, Gerald (ed.). 1982. The Poetry of William VII, Count of Poitiers, IX Duke of Aquitaine (New York: Garland Publishing)

Bond, Gerald A. 20I7. The Loving Subject: Desire, Eloquence, and Power in Romanesque France (Philadelphia: University of Pennsylvania Press)

Bodon, Joan. 1975. 'Tolosa', in Sus la mar de las galèras (Tolosa: I.E.O.), p. 24

Boutière, Jean; Schutz, Alexander H. (ed.). I964. Biographies des troubadours: Textes provençaux des XIIT et XIV siècles, rev. Jean Boutière and I.-M. Cluzel (Paris: A.G. Nizet)

Boyer, Pierre-Louis. 20ıо. Clémence Isaure: Vérités sur une chimère toulousaine (Biarritz: Atlantica)

Brunel, Clovis. 1935. Bibliographie des manuscrits littéraires en ancien provençal (Paris: E. Droz)

Burgwinkle, William E. I993. 'For Love or Money: Uc de Saint Circ and the Rhetoric of Exchange', The Romanic Review, 83: 347-76

Burgwinkle, William E. 1997. Love for Sale: Materialist Readings of the Troubadour Razo Corpus (New York: Garland Publishing)

Catel, Guillaume. I633. Mémoires de l'histoire du Languedoc curieusement et fidèlement recueillis de divers autheurs (Tolose: Pierre Bosc) $<\underline{\text { http://links.uv.es/A36DBia }>}$

Chabaneau, Camille. I885. 'Origine et établissement de l'Académie des Jeux floraux’, in Histoire générale de Languedoc, new edn., ed. Cl. Devic and J. Vaissete (Toulouse: Privat), x: I77-208 $<$ https://tinyurl.com/y3zpxk95>

Chabaneau Camille; Anglade, Joseph. I9II. 'Essai de reconstitution du chansonnier du comte de Sault', Romania, 40: 243-322 <https://doi.org/IO.3406/roma.I9II.4634>

Chabaneau, Camille; Anglade Joseph (ed.). I9I3. Nostredame, Jehan de, Les Vies des plus célèbres et anciens poètes provençaux (Paris: Honoré Champion) $<$ http://links.uv.es/ooAowFP>

Corradini Bozzi, Maria Sofia. 1982-87. Concordanze delle biografie trovadoriche, 2 vols (Pisa: Pacini)

Costa, James. 2009. 'Language History as Charter Myth? Scots and the (Re)invention of Scotland', Scottish Language, 28: I-25<ensl-oo632432><https://core.ac.uk/download/pdf/47740706. $\underline{\mathrm{pdf}}>$ 
Courouau, Jean-François. 2008. Moun lengatge bèl: Les Choix linguistiques minoritaires en France (1490-1660) (Genève: Droz)

Dorian, N. C. 1998. 'Western Language Ideologies and Small-Language Prospects', in Endangered Languages: Current Issues and Future Prospects, ed. by Lenore A. Grenoble and Lindsay J.

Whaley (Cambridge, UK: Cambridge University Press), pp. 3-2I < https://doi.org/Io.IoI7/ CBO978II39I66959.002>

Escudé, Pierre. 20I7. Imprimerie et pouvoir: politique, livre et langue à Toulouse de 1475 à 1617 (Genève: Droz)

Fabre d'Olivet, Antoine (tr.). I803. Le troubadour, poesies occitaniques du XIIr siècle (Paris: Valade) $<$ http://links.uv.es/qoDjuzm>

Fauriel, Claude. I846. Histoire de la poésie provençale, 3 vols (Paris: Labitte)

Fedi, Beatrice. 1999. 'Per un'edizione critica della prima redazione in prosa delle Leys d'amors', Studi Medievali, 40: 43-118

Galvez, Marisa. 2OII. 'From the Costuma d'Agen to the Leys d'Amors: A Reflection on Customary Law, the University of Toulouse, and the Consistori de la Sobregaia Companhia del Gay Saber, Tenso, 26: 30-5I $<\underline{\text { https://doi.org/IO.I353/ten.2OII.0006 }>}$

Gatien-Arnoult, Adolphe-Félix (ed.). I84I. Las Flors del gai saber estier dichas las Leys d'amors, 3 vols (Toulouse: J.-B. Paya)

Gaunt, Simon; Harvey, Ruth; Paterson, Linda (ed.). 200o. Marcabru: A Critical Edition (Cambridge: D. S. Brewer)

Gélis, François de. I9I2. Histoire critique des Jeux floraux depuis leur origine jusqu'à leur transformation en Académie (1323-1694) (Toulouse: Privat) 〈https://tinyurl.com/y4mt4w6w $>$

Gomez de García, Jule; Axelrod, Melissa; Lachler, Jordan. 20o9. 'English is the Dead Language: Native Perspectives on Bilingualism', in Native American Language Ideologies: Beliefs, Practices, and Struggles in Indian Country, ed. by Paul V. Kroskrity and Margaret C. Field (Tucson: University of Arizona Press), pp. 99-I22 $\lfloor\underline{\text { http://tinyurl.com/yy2pujos }>}$

Guida, Saverio; Larghi, Gerardo (ed.). 20I3. Dizionario biografico dei trovatori (Modena: Mucchi Editore)

Harvey, Ruth. 1989. The Troubadour Marcabru and Love (London: Westfield College)

House, Deborah. 2002. Language Shift among the Navajos (Tucson: University of Arizona Press)

Kay, Sarah. 20I3. Parrots and Nightingales: Troubadour Quotations and the Development of European Poetry (Philadelphia: University of Pennsylvania Press)

Kelly, Douglas. 20I8. 'Translatio Poetriae: Occitan Apprenticeship from the Latin Classroom to the Vernacular Court', in Le Poetriae del medioevo latino: modelli, fortuna, commenti, ed. by Gian Carlo Alessio and Domenico Losappio, Filologie medievali e moderne, ${ }_{5}$ (Venezia: Edizioni Ca' Foscari), pp. 9I-I27 〈https://doi.org/IO.30687/978-88-6969-I37-9/005>

Kendrick, Laura. 2008. 'The Consistori del gay saber of Toulouse (I323-circa I484)', in The Reach of the Republic of Letters: Literary and Learned Societies in Late Medieval and Early Modern Europe, ed. by Arjan van Dixhoorn and Susie Speakman Sutch (Leiden: Brill), I: 17-32 <https:// doi.org/IO.II63/ej.9789004I69555.i-522.I3>

Kroskrity, Paul V. 2009. 'Language Renewal as Sites of Language Ideological Struggle: The 
Need for "Ideological Clarification"”, in Indigenous Language Revitalization: Encouragement, Guidance and Lessons Learned, ed. by Jon Allan Reyhner and Louise Lockard (Flagstaff:

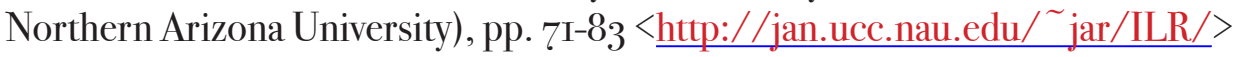

Lafont, Robert. 1970. Renaissance du Sud: Essai sur la littérature occitane au temps de Henri IV (Paris: Gallimard)

Lafont, Robert. 2003. Petita istòria europèa d'Occitània (Canet: Trabucaire)

Leglu, Catherine. 2008. 'Languages in Conflict in Toulouse: Las Leys d'Amors', Modern Language Review, IO3: 383-96 <https://doi.org/IO.2307/20467779>

Leglu, Catherine. 20i6. 'Toulouse', in Europe, a Literary History, ed. by David Wallace (New York: Oxford University Press), I: I4O-55

Lévy-Bruhl, Lucien. 1999. 'Primitive Mentality and Religion', in Classical Approaches to the Study of Religion, ed. by Jacques Waardenburgh (Berlin: Walter de Gruyter), pp. $335^{-52}$

Linskill, Joseph (ed.). 1964. The Poems of the Troubadour Raimbaut de Vaqueiras (Den Haag: Mouton)

Lombardi, Antonella; Careri, Maria. 1998. "Intavulare": tavole di canzonieri romanzi. 1, Canzonieri provenzali: 1: Biblioteca Apostolica Vaticana: A (Vat. Lat. 5232), F (Chig. L.IV.106), L (Vat. Lat. 3206) e O (Vat. Lat. 3208) (Città del Vaticano: Biblioteca Apostolica Vaticana)

Malinowski, Bronislaw. 1954. Magic, Science and Religion, and Other Essays (Garden City, NY: Doubleday Anchor)

Meliga, Walter. 200I. "Intavulare", Tavole di canzonieri romanzi. 1, Canzonieri provenzali: 2: Bibliothèque nationale de France I (fr. 854), K (fr. 12473) (Modena: Mucchi Editore)

Meneghetti, Maria Luisa. 1984. Il pubblico dei trovatori: la recezione della poesia cortese fino al XIV secolo (Torino: Einaudi)

Nostradamus, Caesar de. I6r4. L'histoire et chronique de Provence (Lyon: S. Rigaud) < http://links. uv.es/Zaoi5kz>

Noto, Giuseppe. 1998. Il giullare e il trovatore nelle liriche e nelle 'biografie' provenzali (Alessandria: Edizioni dell’Orso)

Paden, William D. 2019. 'The Etymology of Old Occitan trobar and trobador', Tenso, 34: I-54 $<\underline{\text { https://doi.org/IO.I353/ten.2OIg.OOOI }>}$

Passerat, Georges. 200o. 'L'Église et la poésie: les débuts du Consistori del Gay Saber', Cahiers de Fanjeaux, 35: 443-73

Pfeffer, Wendy. I986. 'Guilhem Molinier as Literary Critic', in Studia Occitanica: In Memoriam Paul Rémy, ed. by Hans-Erich Keller et al. (Kalamazoo, Michigan: Medieval Institute Publications), I: The Troubadours, pp. 205-12

Pirot, François. 1972. Recherches sur les connaissances littéraires des troubadours occitans et catalans des XIIe et XIIIe siècles: Les 'sirventes-ensenhamens' de Guerau de Cabrera, Guiraut de Calanson et Bertrand de Paris, Memorias de la Real Academia de Buenas Letras de Barcelona, I4 (Barcelona: RABLB)

Pirot, François. 1973. 'Le troubadour Eble de Saignes (avec des notes sur Eble de Ventadour et Eble d'Ussel)', in Mélanges de langue et de littérature médiévales offerts à Pierre Le Gentil ([Paris]:

SEDES-CDU), pp. 64I-59 
Poe, Elizabeth Wilson. I99o. 'L'Autr'escrit of Uc de Saint Circ: The Razos for Bertran de Born', Romance Philology, 44: I23-I36 <http://links.uv.es/TgvJeDc $>$

Pollina, Vincent. 199I. Si cum Marcabrus declina: Studies in the Poetics of the Troubadour Marcabru (Modena: Mucchi)

Rajna, Pio. I927. 'Tra le penombre e le nebbie della Gaya Sciensa', in Miscellanea distudi critici in onore di Vincenzo Crescini (Cividale: Stagni), pp. 183-220

Recueil des historiens des Gaules et de la France par des religieux bénédictins de (...) Saint-Maur. I877. ed. Léopold Delisle (Paris: Victor Palmé), XII $\langle\underline{\text { http://links.uv.es/8vocwIC }>}$

Ricketts, Peter T. (ed.). 1976. Le Breviari d'amor de Matfre Ermengaud, tome V(272527-34597) (Leiden: E. J. Brill)

Ricketts, Peter T. (dir.). 2005. Concordance de l'occitan médiéval (Turnhout: Brepols), II [CD$\mathrm{ROM}]$

Roschach, Ernest. I892. 'Une Hypothèse sur la statue de Clémence-Isaure', Mémoires de l'Académie des sciences, inscriptions et belles lettres de Toulouse, $9^{\text {th }}$ ser., 4: I22-I38 <http://links. uv.es/ohhMx2r>

Roschach, Ernest. I896. 'Variations du roman de Clémence Isaure', Mémoires de l'Académie des sciences, inscriptions et belles lettres de Toulouse, $9^{\text {th }}$ ser., 8: $226-263<\underline{\text { http://links.uv.es/ }}$ $\underline{\text { A } 3 \text { rVoh8 }>}$

Rosenstein, Roy. 1988. 'Les Années d'apprentissage du troubadour Jaufre Rudel: de l'escola n'Eblo à la segura escola', Annales du Midi, IOO: 7-I5 <https://doi.org/IO.3406/anami.Ig88.2I49>

Rosenstein, Roy. 2018a. 'Desiring: Jaufre Rudel, Vida', in European Literary History: An Introduction, ed. by Maarten De Pourcq and Sophie Levie (London: Routledge), pp. 97-Io6 $<$ https://doi.org/IO.4324/978I3I57I4622>

Rosenstein, Roy. 20I8b. 'Mythologies', email to the author, 7 December 2018

Rosenstein, Roy. 20I9. 'Care to Read a Paper?', email to the author, 3 January 2019

Rossi, Luciano (ed.). 2009. Cercamon: Oeuvre poétique (Paris: Honoré Champion)

Rossi, Luciano. 20I3. 'Hétéronymie et errance poétiques "autour du monde”: Réflexions sur Ebles II de Ventadour, "Cercamon” et les philologies', Cahiers de civilisation médiévale, 56.2: ${ }_{5}^{\mathrm{I}}$-77

Zufferey, François. I98I. Bibliographie des poètes provençaux des XIV et XV siècles (Genève: Droz)

Zufferey, François. 1987. Recherches linguistiques sur les chansonniers provençaux (Genève: Droz) 